\title{
Postharvest Decay Risk Associated with Hydrocooling Tomatoes
}

Clément Vigneault, Horticultural Research and Development Centre, Agriculture and Agrifood Canada, SaintJean-sur-Richelieu, Québec, Canada, J3B 3E6, Jerry A. Bartz, Plant Pathology Department, University of Florida, Gainesville, 32611, and Steven A. Sargent, Horticultural Sciences Department, University of Florida, Gainsville 32611

\begin{abstract}
Vigneault, C., Bartz, J. A., and Sargent, S. A. 2000. Postharvest decay risk associated with hydrocooling tomatoes. Plant Dis. 84:1314-1318.

Tomatoes (breaker stage) hydrocooled with a cell suspension of Erwinia carotovora subsp. carotovora containing 50 to $200 \mathrm{mg}$ of free chlorine per liter (ppm) $\left(10^{\circ} \mathrm{C}, \mathrm{pH} 7\right)$ remained decay free during a 10-day storage at $20^{\circ} \mathrm{C}$. Sporadic disease appeared during storage of tomatoes similarly cooled with chlorinated water containing spores of Rhizopus stolonifer. In contrast, when chlorine was omitted from the pathogen suspensions, 50 to $100 \%$ of the fruit became diseased. A laboratory-scale shower hydrocooler reduced fruit temperatures from 35 to $15^{\circ} \mathrm{C}$ within $13.3 \mathrm{~min}$, whereas a flume cooler produced the same temperature reduction in $10.5 \mathrm{~min}$. In both systems, tomatoes increased in weight during cooling, evidence for water uptake. Larger weight increases occurred among tomatoes cooled in the shower than in the flume. An upward instead of downward orientation of stem scars under the shower streams led to significantly larger weight increases, presumably because pores in the stem scar were continuously flooded with water. Tomatoes intermittently submerged in cold water (10 2-min immersions followed by 30 -s pauses) absorbed significantly less water than those continuously submerged for $20 \mathrm{~min}$. Hydrocooling appears to be a viable method for rapid cooling of tomatoes. Technical refinements in the hydrocooling process that prevent continuous coverage of fruit surfaces by water should reduce water uptake and the associated risk of pathogen internalization. Maintenance of free chlorine at up to $200 \mathrm{ppm}$ in the cooling water and prevention of direct water pressure on fruit should minimize decay risks. No evidence of phytotoxicity was observed among fruit infiltrated with $200 \mathrm{ppm}$ of chlorine. These tomatoes ripened similarly to those that were not cooled or were cooled in tap water.
\end{abstract}

Additional keywords: bacterial soft rot, Lycopersicon esculentum, microbe internalization, sodium hypochlorite

Cooling fruit and vegetables after they have been packaged is a primary method for maintaining quality and preventing decay during storage and marketing (5). Sommer (16) noted that refrigeration was so critical to the control of postharvest diseases that other treatments may be considered supplements. Currently, many tomatoes are harvested green and packed in 11.34-kg (25-lb) cartons, which are stacked on pallets in closed rooms and treated with ethylene gas to promote ripening. Cooled air $\left(20^{\circ} \mathrm{C}\right)$ circulates in the "ripening" rooms, but such rooms usually do not have structures that force air through the fruit containers. Consequently, tomatoes in the center of the stacks may have pulp temperatures of up to $35^{\circ} \mathrm{C}$ and are cooled slowly and sporadically leading to non-

Corresponding author: J. A. Bartz

E-mail: jabar@gnv.ifas.ufl.edu

Journal Series Article R-07804 of the Florida Agricultural Experiment Station, Gainesville.

Accepted for publication 30 August 2000.

Publication no. D-2000-1016-03R

(C) 2000 The American Phytopathological Society uniform ripening (M. T. Talbot and J. K. Brecht, unpublished data). Additionally, slow room cooling can lead to excessive water loss, particularly at the edges of the carton stacks (13). Prolonged high pulp temperatures in tomatoes have been associated with poor quality as well as a failure to ripen $(9,11)$.

Temperatures of packaged tomatoes could be reduced rapidly by forced-air cooling, where cool room air moves through rather than around the stacks of products (10). Hydrocooling, where products are drenched by or immersed in cold water, is a more efficient method for removing field heat (7). Certain fresh fruit and vegetables such as strawberries, however, are not hydrocooled because of concerns that contact with water leads to postharvest decay (8).

Whether tomatoes can be hydrocooled without risking excessive postharvest disease is unclear. The fresh-market tomato industry uses water-filled receiving tanks and flumes to minimize mechanical injury to fruit that are being transferred from field bins to the packing line. This exposure to water creates a postharvest decay risk $(2,4,14)$. The water is recycled during a workday, which can lead to an accumula- tion of pathogens that have been washed from the tomatoes. Contaminated water spreads pathogens to likely infection courts such as wounds on fruit. Moreover, under certain conditions, water and pathogens can enter pores on fruit surfaces (2-4). Tissues inside tomatoes apparently lack a protective cuticle because internalized wound pathogens such as Erwinia carotovora subsp. carotovora or Geotrichum candidum rapidly initiate decay. Such lesions expand quickly, leading to large amounts of decayed tissue and rapid secondary spread of disease.

Pathogens enter tomatoes when pores located at the stem scar and corky ring of the fruit are infiltrated with water (2-4). Waxes on the fruit's surface hinder the penetration of pores by water unless gas pressure inside the fruit is considerably less than that at the fruit surface (2). Cooling submerged fruit or hydrostatic pressure on fruit surfaces can produce the pressure imbalances that cause water to infiltrate the pores $(2,4)$. Gas pressures inside cooling fruits decrease as predicted by the Ideal gas law (4). The resulting partial vacuum pulls water into the fruit. In contrast, submerging fruit in water or the impact of water on fruit surfaces can create a sufficient hydrostatic pressure to force water into the pores (2).

Dump tanks, flumes, and hydrocoolers are usually sanitized by water chlorination (5). Whether chlorination of a hydrocooler would inactivate pathogens before they are internalized by cooling fruit is not clear. Bartz (3) observed significant decay (above the $5 \%$ allowed by grade standards) among tomatoes that had been pressureinfiltrated while submerged in chlorinated water contaminated with $E$. carotovora subsp. carotovora. Moreover, in three separate tests, fruit treated in chlorinated water gained more weight than those treated in contaminated water. By contrast, Ferreira et al. (8) observed that the decay risk associated with cooling bruised strawberries in pathogen-contaminated water (Rhizopus stolonifer or Botrytis cinerea) was eliminated if chlorine was added just prior to adding the berries.

The objective of this project was to compare the decay risk associated with cooling tomatoes with two types of hydrocoolers. Recently harvested tomatoes were cooled in various ways with water containing chlorine and two common postharvest pathogens, E. carotovora subsp. 
carotovora, cause of bacterial soft rot, and $R$. stolonifer, cause of Rhizopus rot.

\section{MATERIALS AND METHODS}

Pathogen and tomato fruit preparation. Aqueous suspensions of E. carotovora subsp. carotovora were prepared from 24-h nutrient broth cultures of Florida strains SR38 or SR12 that had been grown and harvested as previously described (1). Cell density in the stock suspensions was measured with a spectrophotometer (Spectronic 20, Bausch and Lomb, Inc., Rochester, NY). R. stolonifer, originally isolated from strawberries, was grown on potato dextrose agar (PDA) for 3 to 5 days. The cultures were flooded with sterile tap water and then brushed with a flamed, bent-glass spreader. The resulting suspension was centrifuged to remove particulate matter. The pellet was suspended in sterile tap water and filtered through cheesecloth. The density of the suspensions was measured with a spectrophotometer.

Tomatoes ('Agriset' or 'FTE12') were selectively hand-harvested from commercial fields in South Florida. Agriset tomatoes had stems attached at "Stage 2 ripeness" (defined as break in color from green to tannish yellow, pink, or red on $\leq 10 \%$ of the fruit surface) and weighed between 200 and $250 \mathrm{~g}$ each. FTE12 tomatoes were "mature green," of variable size, and were removed from stems during harvest. The tomatoes were carefully sorted to avoid bruises, cracks, or other damage and distributed randomly among treatments.

Hydrocooler design. A drench hydrocooler was built from a galvanized metal cabinet $(50 \times 45 \times 85 \mathrm{~cm})$ with a drain. The top of the cabinet was recessed (6.5 $\mathrm{cm}$ ), which provided a water reservoir. The front was open to provide access to the interior. A hardware-cloth shelf was fastened half way between the bottom of the cabinet floor and the reservoir. Five perforated metal plates $(460 \times 800 \mathrm{~mm})$ each with five holes of $9 \mathrm{~mm}^{2}$ (cross-sectional area-holes) placed on the bottom of the reservoir provided a drench for the first level of tomatoes. Five metal canning lid rings $(70 \mathrm{~mm}$ in diameter) for 0.946-liter (1-qt) glass jars were placed on the hardware cloth beneath the perforated plates. Five cut-in-half $0.373-\mathrm{kg}$ (1-lb) coffee cans (100 $\mathrm{mm}$ diameter), each with five holes of the same size as those on the plates, were fastened under the hardware cloth beneath the lid rings. An inverted dinner tray placed on the bottom of the cabinet held a lid ring beneath each coffee can. Cool water $\left(10^{\circ} \mathrm{C}\right)$ was supplied to the reservoir by a liquid circulator (PolyScience 960 Preston Industries, Inc., Niles, IL) at 166 to $250 \mathrm{ml} \mathrm{s}^{-1}$. A tomato was placed on each lid ring. The water went through the perforated plates drenching the tomatoes with approximately 1,000 liters $\mathrm{min}^{-1} \mathrm{~m}^{-2}$ (13). The coffee cans caught the water draining off the first layer of fruits and directed it over a second layer of five fruits. This design prevented the fruits from becoming partially immersed in water during the cooling process and cooled fruits in both layers from pulp temperatures of 35 to $15^{\circ} \mathrm{C}$ in 13.3 minutes, based the temperature measurement method of Smith and Bennett (15).

A "flume" hydrocooler was made of Plexiglas, $10 \mathrm{~cm}$ wide and high and 100 $\mathrm{cm}$ long. A plate with 10 holes was fastened to one end. The entrance was partially covered by a solid Plexiglas plate that was clamped to the flume, leaving an opening of $2.5 \times 10 \mathrm{~cm}$. Plastic mesh 0.946-liter (1-qt) strawberry baskets were installed at the water inlet and outlet to contain the fruit and prevent direct water currents. Water was circulated from the liquid circulator described above through the trough and around the fruit at a mean water velocity of approximately $0.76 \mathrm{~m} \mathrm{~s}^{-1}$. The fruit was oriented with the stem scar beneath the surface of the water at about a $30^{\circ}$ angle from vertical. Five tomatoes were placed near the water inlet and five near the water outlet. This flume system cooled the fruit from the initial $35^{\circ} \mathrm{C}$ to $15^{\circ} \mathrm{C}$ within $10.5 \mathrm{~min}$. The liquid circulator maintained a constant water temperature $\left(10^{\circ} \mathrm{C}\right)$ during the entire cooling procedure for both systems.

Preliminary tests on factors associated with hydrocooling. Tomatoes were cooled intermittently rather than continuously to find if periodically removing water from fruit surfaces during the cooling would prevent or reduce infiltration. The fruit (FTE12) were warmed to $40^{\circ} \mathrm{C}$ (pulp temperature of a test fruit measured with a glass thermometer) and then submerged in a $\log _{10} 6.0 \mathrm{CFU} / \mathrm{ml}$ suspension of E. carotovora subsp. carotovora at $20^{\circ} \mathrm{C}$ for 20 min. Tomatoes were weighed before and after treatment to measure the quantity of water absorbed. In subsequent treatments, the 20-min immersion period was interrupted by 2 to 10 equally spaced, 30-s periods, during which the fruit was removed and held stem scar downward to allow water to drain. The final pulp temperature of a single average-sized fruit included in the treatment was recorded. The treated tomatoes were stored at $30^{\circ} \mathrm{C}$ for 5 days to allow decay development. Tomatoes were observed daily during storage and decay incidence and lesion location were recorded. Development of lesions beside or beneath the stem scar or associated with the blossom scar confirmed the internalization of viable cells of $E$. carotovora subsp. carotovora as fruit was infiltrated by the cooling medium.

Contaminated water used to cool fruit was chlorinated to find if such treatment eliminated the decay risk associated with pathogen internalization during cooling. Warm $\left(37^{\circ} \mathrm{C}\right)$ tomatoes (FTE12) were immersed for $10 \mathrm{~min}$ in cool $\left(20^{\circ} \mathrm{C}\right)$ contami- nated water to which chlorine had been added. Contamination came from the maceration (blended at high speed for $30 \mathrm{~s}$ ) of two partially decayed fruits (ca. $550 \mathrm{~g}$ ) in $250 \mathrm{ml}$ of deionized water. A 400-ml volume of macerate was added to 6 liters of tap water. The mixture was stirred and the fruit were immediately placed in the mixture (fruit addition required an estimated 10 to $15 \mathrm{~s}$ ). After the control fruit had been treated and removed, shaved ice was used to reduce the suspension temperature back to $20^{\circ} \mathrm{C}$. A $24-\mathrm{ml}$ sample of laundry bleach was added to provide a calculated $200 \mathrm{ppm}$ of chlorine. The mixture was stirred and the fruit immediately added. The 400-ppm chlorine treatment involved fresh water, the last 400-ml sample of macerated fruits, and $48 \mathrm{ml}$ of laundry bleach. The $\mathrm{pH}$ of the chlorinated water was not adjusted.

Cooling tomato fruits with an experimental hydrocooler. Tomatoes with stems were stored overnight at $35^{\circ} \mathrm{C}$. Just before hydrocooling, fruit were stemmed and weighed. After treatment, fruit were dried with a towel and weighed to determine water uptake. Control treatments included fruit that had not been exposed to water, fruit exposed to clean water but not hydrocooled, and fruit that had been hydrocooled in clean tap water.

For the different chlorine levels, liquid laundry bleach containing $5.25 \%$ sodium hypochlorite was added to 28 liters of tap water at $10^{\circ} \mathrm{C}$ to provide $0,50,100,150$, or $200 \mathrm{mg}$ per liter (ppm) of free chlorine. The $\mathrm{pH}$ of the chlorinated water was adjusted to 7 to 7.5 by the addition of $1 \mathrm{M}$ $\mathrm{HCl}$. Total chlorine concentrations were measured with a High-Range Chlorine Test Kit (model CN-21P, Hach, Inc., Loveland, $\mathrm{CO}$ ). The tomatoes were added to the water first and the pathogens immediately afterward. The same water was used for each treatment. A water sample was spread on nutrient agar or acidified PDA to determine if viable pathogen structures were present at the conclusion of each treatment.

All fruit were stored stem-scar up in a multicup tray at $20^{\circ} \mathrm{C}$ and examined daily. Diseased tomatoes were cut in half through the stem scar to identify the origin of the lesion, e.g., stem scar, blossom scar, or wounds. This procedure continued until $90 \%$ of the tomatoes were table ripe (full red and beginning to soften, which occurred approximately 10 days after treatment). All tomatoes that appeared healthy at the completion of storage were cut open through the stem and blossom scars to find if a latent infection or phytotoxicity was present in tissues likely to have been infiltrated (3).

Effect of orientation of stem scar on infiltration of tomatoes in a shower hydrocooler. Tomatoes were placed on the lid rings, stem scar up or down, and drenched with a cool suspension $\left(1 \times 10^{5}\right.$ spores per $\mathrm{ml}$ ) of $R$. stolonifer with or without up to $200 \mathrm{ppm}$ chlorine at $\mathrm{pH} 7$. 
The spore suspension and the chlorine stock were added to the water just prior to starting the drench treatment. There were five tomatoes in each treatment.

Effect of cooling system design on the infiltration of hydrocooled tomatoes. Tomatoes were cooled in suspensions of $E$. carotovora subsp. carotovora $\left(1 \times 10^{6}\right.$ $\mathrm{CFU}$ per $\mathrm{ml})$ or $R$. stolonifer $\left(1 \times 10^{5}\right.$ spores $/ \mathrm{ml}$ ) containing up to $200 \mathrm{ppm}$ chlorine ( $\mathrm{pH} 7)$. The sequence of the first set of cooling treatments was, with respect to chlorine concentration and cooler design: 0 ppm, flume; $50 \mathrm{ppm}$, shower; $100 \mathrm{ppm}$, flume; $150 \mathrm{ppm}$, shower; and $200 \mathrm{ppm}$, flume. There was a 5-min delay between adding the chlorine and initiating the test at each chlorine concentration to assure equilibration in the system. The pathogen suspensions and chlorine stock solutions were added to the circulating water just after the fruit was placed in position. After the final treatment in the first series of tests, the water was drained and all instruments and the cooling system were washed with chlorinated water, rinsed with tap water, and filled with tap water at $10^{\circ} \mathrm{C}$, which was treated with thiosulfate to remove residual free chlorine. The second set of treatments was $0 \mathrm{ppm}$, shower; $50 \mathrm{ppm}$, flume; $100 \mathrm{ppm}$, shower; $150 \mathrm{ppm}$, flume; and $200 \mathrm{ppm}$, shower. Then the entire experiment was repeated. There were five tomatoes arranged in each of two locations in the cooler for a total of 10 per treatment. In the shower cooler, tomatoes were in two layers, stem scars down. A similar experiment was subsequently performed with $R$. stolonifer using a second fruit lot.

Effect of hydrocooling in chlorinated water on fruit firmness, maturity index, and color. Flesh firmness at the end of the storage period was measured by deformation using a $15-\mathrm{mm}$ convex probe with a $1.0-\mathrm{kg}$ static weight applied for $5 \mathrm{~s}$. Color was measured by colorimeter (Minolta CR-200, $8 \mathrm{~mm}$ aperture, CIE L*a*b*, illuminant D65 d/0, standard calibration). Ripeness was evaluated as stage 1 to 6 using the visual color classification requirements for tomatoes (USDA).
Statistical analyses. The experimental designs in the hydrocooling tests were balanced and a dynamic cross table constructed including only positive controls (fruits cooled in contaminated water). Negative and positive controls were compared using an orthogonal contrast. A 4way analysis of variance was performed with fixed effects on each dependent variable with the program SAS on PC (SAS Institute, Cary, NC). When $F$ was high enough to permit a significant level of $P$, the treatments were separated to distinguish which one produced significant changes in the dependent variables. The LSD test was done on certain parameters. Orthogonal contrasts were performed on weight increase and disease incidence to detect effects of the different chlorine concentrations.

\section{RESULTS}

Preliminary tests on factors associated with hydrocooling. Warm fruit submerged in cool water four times for $5 \mathrm{~min}$ each gained an average of $0.79 \mathrm{~g}$ per tomato, whereas those submerged once for $20 \mathrm{~min}$ gained $0.74 \mathrm{~g}$ per tomato (Table 1). The temperature reduction was similar. By contrast, fruit immersed 10 times for $2 \mathrm{~min}$ each had nearly the same temperature reduction but gained significantly less weight. Lesions developed within $48 \mathrm{~h}$ of storage. All lesions were located beside or beneath either the stem or the blossom scar. Only one of 10 tomatoes treated with the $10 \times 2$-min immersions was diseased at the initial observation, whereas four to nine of tomatoes in the other exposures had at least one lesion. Tomatoes at $20^{\circ} \mathrm{C} \mathrm{im-}$ mersed in the $20^{\circ} \mathrm{C}$ inoculum for $20 \mathrm{~min}$ did not increase in weight, and only one of 10 tomatoes developed soft rot during storage for 5 days at $30^{\circ} \mathrm{C}$.

In a second preliminary test, 17 of 20 tomatoes immersed for $10 \mathrm{~min}$ in water contaminated with decaying fruit (fruit temperature $=37^{\circ} \mathrm{C}$; water temperature $=$ $20^{\circ} \mathrm{C}$ ) developed postharvest decay within 7 days stored at $26^{\circ} \mathrm{C}$ (not shown). By contrast, only one of 20 fruit decayed if 200 ppm chlorine was added to the water, whereas no decay was found during a total storage period of 14 days when the contaminated water bath contained $400 \mathrm{ppm}$ chlorine. The average weight gain for 10 representative fruit in the control treatment was $0.5 \mathrm{~g}$.

Effect of the orientation of the stem scar on infiltration of tomatoes in a shower hydrocooler. An upward orientation of stem scars on fruit cooled in the drench cooler led to greater weight increase than did the downward orientation (1.02 versus $0.45 \mathrm{~g} /$ fruit, respectively, $P=$ 0.0011) (Table 2). The range in weight increase for stem scars up versus down was 0.0 to $2.1 \mathrm{~g}$ per tomato versus 0.0 to $1.7 \mathrm{~g}$ per tomato, respectively. Except for one fruit, however, decay occurred only among fruit cooled in the suspension of $R$. stolonifer. The addition of chlorine to the water prevented decay associated with infiltration. Additionally, the chlorine addition led to a reduction in water absorbed (contrast of average weight increase for fruit treated without chlorine versus average for fruit in all chlorine treatments was significant at $P$ $=0.0001$ ). Water samples plated after each chlorinated water treatment were negative for the test fungus, whereas the pathogen was detected after the control treatment. Disease was not found among fruit not treated with water or cooled in clean water alone. There was no evidence of phytotoxicity or hidden infections among "healthy" fruit that were cut open after the 10-day storage.

Effect of cooling system design on the infiltration of hydrocooled tomatoes. Tomatoes cooled by either flume or shower hydrocooling increased in weight. In the tests with E. carotovora subsp. carotovora, fruit increased in weight by an average of 0.04 to $0.15 \%$ (Table 3 ). The location of tomatoes inside the shower or flume did not affect the weight increase. The quantity of water absorbed ranged from 0.02 to 0.42 $\mathrm{g}$ per fruit. Although tomato weights were measured to $0.01 \mathrm{~g}$, weight increases smaller that about $0.04 \mathrm{~g}$ may not represent water absorption. Air currents and other factors affected hundredth of gram measurements. Fruits cooled under the shower

Table 1. Weight increase and decay incidence associated with immersion of tomatoes ('FTE12') at $37^{\circ} \mathrm{C}$ in a suspension of Erwinia carotovora subsp. carotovora $^{\mathrm{a}}$ at $20^{\circ} \mathrm{C}$ for total of $20 \mathrm{~min}$ but with different exposure intervals ${ }^{\mathrm{b}, \mathrm{c}}$

\begin{tabular}{|c|c|c|c|c|c|}
\hline \multirow[b]{2}{*}{ Exposures } & \multirow[b]{2}{*}{ Duration (min) } & \multirow[b]{2}{*}{ Final fruit temp. $\left({ }^{\circ} \mathrm{C}\right)$} & \multirow[b]{2}{*}{ Weight increase (\%) } & \multicolumn{2}{|c|}{ Decay incidence (\%) } \\
\hline & & & & 2 days & 3 days \\
\hline 1 & 20 & 27.0 & $0.45^{\mathrm{d}}$ & 70 & 80 \\
\hline 2 & 10 & 27.0 & 0.48 & 90 & 100 \\
\hline 4 & 5 & 27.5 & 0.48 & 40 & 100 \\
\hline 10 & 2 & 28.0 & 0.11 & 10 & 50 \\
\hline \multirow[t]{3}{*}{ Control $^{\mathrm{e}}$} & NA & 20.0 & 0.00 & 0 & 0 \\
\hline & & & $\mathrm{LSD}=0.23$ & & \\
\hline & & & $P=0.05$ & & \\
\hline
\end{tabular}

\footnotetext{
${ }^{a}$ Florida Strain SR12 at $1 \times 10^{6} \mathrm{CFU} / \mathrm{ml}$.

b Tomatoes were removed from the water and placed stem scar down for $30 \mathrm{~s}$ between each interval.

c After treatment tomatoes were stored at $30^{\circ} \mathrm{C}$.

${ }^{d}$ Each value is the average of 10 tomatoes.

e Tomatoes at $20^{\circ} \mathrm{C}$ were submerged for $20 \mathrm{~min}$ in a suspension at $20^{\circ} \mathrm{C}$.
} 
increased in weight more than those cooled in the flume $(P=0.009)$. Decay developed only among fruit cooled in the nonchlorinated suspension.

In tests with $R$. stolonifer, which involved a different fruit lot, weight increases among individual fruit in the different chlorine treatments ranged from $0.04 \%$ (0.08 to $0.10 \mathrm{~g}$ per tomato) to $0.55 \%$ ( 1.1 to $1.37 \mathrm{~g}$ per tomato) (Table 4 ). Fruit cooled under the shower absorbed more water than those cooled in the flume $(0.096 \%$ vs. $0.284 \%$, respectively, $P=$ $0.0001)$. Decay was primarily observed among fruit that had been cooled in the nonchlorinated suspension. Sporadic occurrence of disease, however, was observed among fruit treated with chlorinated water plus the spore suspension.

Effect of hydrocooling in chlorinated water on fruit firmness, maturity index, and color. The two fruit lots used $(P=$ $0.0001)$ significantly influenced firmness of the treated fruit (Newtons). Fruit in the second lot, used in the $R$. stolonifer tests, were firmer when at a full red color than those used in the E. carotovora subsp. carotovora tests. In contrast, neither cooling method nor water chlorination affected firmness. The color (hue angle) of the ripened fruit from the second lot was slightly less red than that in the first lot $(P=$ 0.0001), whereas there were no differences associated with cooling method or the addition of chlorine to the water.

\section{DISCUSSION}

The potential of hydrocooling as a commercial practice depends on whether water infiltrates the cooling fruit or carries with it the associated risk of postharvest decay $(2,4)$. Bartz (3) reported that water chlorination did not fully protect tomatoes exposed to pressure infiltration while submerged in water contaminated with $E$. carotovora subsp. carotovora. Moreover, the chlorine increased the amount of water entering the fruit. Water chlorination is the current standard sanitation treatment for packinghouse water systems (5). A preliminary test reported here, however, suggested that water chlorination may be more effective in reducing the decay risk associated with infiltration if the latter is caused by temperature difference instead of water pressure. A second preliminary test suggested that intermittent water coverage of the pores in a tomato's surface did not produce as much infiltration as continuous coverage even though total exposure periods and temperature changes were similar.

The two types of laboratory-scale, model hydrocoolers used here rapidly cooled warm tomatoes to desirable temperatures for ripening $(9,11)$. A shower or drench hydrocooler reduced pulp temperatures from 35 to $15^{\circ} \mathrm{C}$ in $13.3 \mathrm{~min}$, whereas a flume cooler did so in $10.5 \mathrm{~min}$. Neverthless, fruit increased in weight during treatment in either design, evidence of water infiltration (4). In separate tests with two different pathogens, tomatoes cooled under a shower of water increased in weight more than fruits cooled in a flume of water apparently reflecting a longer period of exposure. Although tomatoes' temperature change was the same in both coolers, the tomatoes were in the water 2.8 min longer in the shower that in the flume. Additionally, an upward instead of downward stem scar orientation in the shower cooler led to increased infiltration, apparently due to the pooling of water over the pores in the stem scar region. Pores in the stem scar are connected to extensive intercellular spaces, and movement of ink dur-

Table 2. Percent weight increase during treatment and percent decay incidence during storage of tomatoes shower-cooled with stem scar up or down in chlorinated water amended with spores of Rhizopus stolonifer $\mathrm{r}^{\mathrm{a}, \mathrm{b}, \mathrm{c}}$

\begin{tabular}{lccccc}
\hline & \multicolumn{2}{c}{ Up } & & \multicolumn{2}{c}{ Down } \\
\cline { 2 - 3 } \cline { 5 - 6 } Chlorine conc. $(\mathbf{p p m})$ & Weight incr. (\%) & Decay (\%) & & Weight incr. (\%) & Decay (\%) \\
\hline 0 & $0.77^{\mathrm{d}}$ & $100^{\mathrm{e}}$ & & 0.33 & 100 \\
50 & 0.56 & 0 & & 0.19 & 0 \\
100 & 0.58 & 20 & & 0.21 & 0 \\
150 & 0.10 & 0 & & 0.11 & 0 \\
200 & 0.26 & 0 & & 0.17 & 0 \\
\hline
\end{tabular}

a Approximately 200- to 250-g 'Agriset' tomatoes were selectively harvested at stage 2 of ripeness (breaker), stored overnight at $35^{\circ} \mathrm{C}$, and sorted for freedom from defects; stems were removed and each tomato was weighed.

b Tomatoes were cooled to $15^{\circ} \mathrm{C}$ in 13.3 min with stem scars exposed to shower (up) or hidden from direct shower (down), with water at $10^{\circ} \mathrm{C}$ and then were wiped dry, reweighed, and stored at $20^{\circ} \mathrm{C}$ for 10 days. Mean weight increase for tomatoes cooled in the suspension alone exceeded the mean for tomatoes cooled in chlorinated suspension at $P=0.0001$. Mean weight increase for fruit cooled with stem scars upward exceeded that for tomatoes cooled downward at $P=0.0011$.

${ }^{\mathrm{c}}$ Spores of $R$. stolonifer added to $1 \times 10^{5}$ spores per $\mathrm{ml}$.

${ }^{\mathrm{d}}$ Each value is the average of five tomatoes.

${ }^{\mathrm{e}}$ Decay incidence among five tomatoes.

Table 3. Weight increase during cooling and decay incidence in storage of tomatoes hydrocooled by two methods with a suspension of Erwinia carotovora subsp. carotovora containing chlorine $\mathrm{e}^{\mathrm{a}, \mathrm{b}, \mathrm{c}}$

\begin{tabular}{lccccc}
\hline & \multicolumn{2}{c}{ Flume } & & \multicolumn{2}{c}{ Shower } \\
\cline { 2 - 3 } \cline { 5 - 6 } Chlorine conc. (ppm) & Weight incr. (\%) & Decay (\%) & & Weight incr. (\%) & Decay (\%) \\
\hline 0 & $0.04^{\mathrm{d}}$ & $15^{\mathrm{e}}$ & & 0.12 & 50 \\
50 & 0.05 & 0 & & 0.08 & 0 \\
100 & 0.04 & 0 & & 0.03 & 0 \\
150 & 0.02 & 0 & & 0.04 & 0 \\
200 & 0.15 & 0 & & 0.07 & 0 \\
\hline
\end{tabular}

${ }^{a}$ Approximately 200- to 250-g 'Agriset' tomatoes were selectively harvested at stage 2 of ripeness (breaker), stored overnight at $35^{\circ} \mathrm{C}$, and sorted for freedom from defects; stems were removed and each tomatoes was weighed.

b Tomatoes were cooled to $15^{\circ} \mathrm{C}$ in $13.3 \mathrm{~min}$ or $10.5 \mathrm{~min}$ by shower or flume cooling, respectively, with a water temperature of $10^{\circ} \mathrm{C}$ and then were wiped dry, reweighed, and stored at $20^{\circ} \mathrm{C}$ for 10 days.

${ }^{\mathrm{c}}$ Initial concentration of E. carotovora subsp. carotovora (Florida strain SR38) $\log _{10} 6.0 \mathrm{CFU} / \mathrm{ml}$.

${ }^{\mathrm{d}}$ Each value is the average for 10 tomatoes in each of two separate tests. Mean weight increase for shower cooled fruits exceeds that for flume cooled tomatoes at $P=0.009$.

${ }^{\mathrm{e}}$ Each value is the average of two separate tests with 10 tomatoes in each.

Table 4. Percent weight increase during cooling and percent decay incidence in storage for tomato fruits hydrocooled by two methods in chlorinated water supplemented with a suspension of Rhizopus stolonifer ${ }^{\mathrm{a}, \mathrm{b}, \mathrm{c}}$

\begin{tabular}{lccccc}
\hline & \multicolumn{2}{c}{ Flume } & & \multicolumn{2}{c}{ Shower } \\
\cline { 2 - 3 } \cline { 5 - 6 } Chlorine conc. (ppm) & Weight incr. (\%) & Decay (\%) & & Weight incr. (\%) & Decay (\%) \\
\hline 0 & $0.07^{\mathrm{d}}$ & $15^{\mathrm{d}}$ & & 0.41 & 80 \\
50 & 0.05 & 5 & & 0.31 & 0 \\
100 & 0.18 & 0 & & 0.35 & 5 \\
150 & 0.11 & 0 & & 0.16 & 0 \\
200 & 0.08 & 5 & 0.19 & 0 \\
\hline
\end{tabular}

a Approximately 200- to 250-g 'Agriset' tomatoes were selectively harvested at stage 2 of ripeness (breaker), stored overnight at $35^{\circ} \mathrm{C}$, and sorted for freedom from defects; stems were removed and each tomato was weighed.

${ }^{\mathrm{b}}$ Tomatoes were cooled to $15^{\circ} \mathrm{C}$ in $13.3 \mathrm{~min}$ or $10.5 \mathrm{~min}$ by shower or flume cooling, respectively, with a water temperature of $10^{\circ} \mathrm{C}$ and then were wiped dry, reweighed, and stored at $20^{\circ} \mathrm{C}$ for 10 days. Mean weight increase for shower cooled fruit exceed that for flume cooled fruit at $P=$ 0.0001 .

${ }^{\mathrm{c}}$ Initial concentration of $R$. stolonifer in the water was $1 \times 10^{5}$ spores per ml.

${ }^{\mathrm{d}}$ Each value is the average for 10 tomatoes in each of two separate tests. 
ing infiltration of fruit by India ink occurs primarily through the stem scar (4).

When 50 to $200 \mathrm{ppm}$ of chlorine was added to the water in the hydrocooler, decay associated with weight increase was entirely prevented when E. carotovora subsp. carotovora contaminated the water, but sporadic disease development was observed when $R$. stolonifer was used. This difference might be attributed to the relative volume of suspension absorbed or to the relative insensitivity of fungal spores to chlorine as compared with bacterial cells (18). Nevertheless, several tomatoes in the stem scar orientation test that absorbed

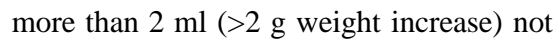
only survived the 10-day storage, but also appeared healthy internally when cut open at the end of the storage. Thus, infiltration of fruit by a large volume of chlorinated water, by itself, would not explain the sporadic occurrence of disease.

When $50 \mathrm{ppm}$ of chlorine was added to the water the majority of $R$. stolonifer spores were inactivated before being internalized. Ferriera et al. (8) observed that more than $80 \mathrm{ppm}$ of chlorine was needed to inactivate spores of $R$. stolonifer in a $5^{\circ} \mathrm{C}$ suspension within a 2 -min treatment. The apparently greater sensitivity to chlorine of the spores tested here could be due to a higher water temperature, i.e., $5^{\circ} \mathrm{C}$ versus $10^{\circ} \mathrm{C}(19)$. Alternatively, if infiltration does not begin within $2 \mathrm{~min}$, spores would likely be exposed to chlorine for more than 2 min before they begin entering the fruits. A longer exposure generally enhances the efficacy of chlorine for controlling microorganisms (19).

The infiltration of fruit with water or chlorinated water did not cause apparent damage other than increase the decay potential. Fruit cracking as observed by Studer and Kader (17), who immersed freshly harvested tomatoes in water for 15 to $120 \mathrm{~min}$, did not accompany the weight increases observed here. The uptake of chlorinated water by tomato tissues did not cause phytotoxicity such as observed previously in fruit pressure-infiltrated with high concentrations of chlorine (3). Neither fruit color nor texture was affected by hydrocooling or by infiltration with water containing up to $200 \mathrm{ppm}$ free chlorine. Infiltration was not increased by water chlorination, contrary to the report by
Bartz (3), for tomatoes pressure-treated with chlorine solutions at ambient temperature (approximately $24^{\circ} \mathrm{C}$ ). Chlorine is more reactive at $24^{\circ} \mathrm{C}$ than at $10^{\circ} \mathrm{C}$, which was used in this study $(18,19)$. Additionally, with pressure treatment, forces responsible for infiltration develop instantaneously with the application of air pressure to the submerged tomatoes. With temperature reduction-induced infiltration, the pressure difference develops as the tissues cool. Bartz (3) observed decay and evidence of internalization of inoculum in tomatoes pressure-infiltrated with chlorinated suspensions of E. carotovora subsp. carotovora. None of the fruits cooled in chlorinated suspensions of E. carotovora subsp. carotovora developed decay in this study. This suggests that instant pressures on fruit surfaces begin internalizing inoculum more quickly than developing pressures.

The sporadic development of Rhizopus rot among fruit infiltrated with water containing up to $200 \mathrm{ppm}$ free chlorine at $\mathrm{pH}$ 7.0 (Table 4) remains a concern for use of hydrocooling commercially. "Wet boxes," a term used by packinghouse managers to describe wet spots on tomato boxes that have been caused by one or more decaying fruit, can cause buyers to back out of agreements or to request discounts. A single tomato that has been infiltrated with spores of $R$. stolonifer could cause a wet box. Furthermore, the infiltration by handling or cooling water of a raw agricultural product that is intended for fresh consumption raises human health concerns $(6,12)$.

\section{ACKNOWLEDGMENTS}

We thank Abbie Fox, Janine Caron, Eliamar Coelho, Sylvain Côté, Carole Brodeur, Pierre Lemoyne, Gaétan Bourgeois, and Jennifer DeEll for their assistance during testing or in analysis of results or in the preparation of the manuscript.

\section{LITERATURE CITED}

1. Bartz, J. A. 1981. Variation in the latent period of bacterial soft rot in tomato fruit. Phytopathology 71:1057-1062.

2. Bartz, J. A. 1982. Infiltration of tomatoes immersed at different temperatures to different depths in suspensions of Erwinia carotovora subsp. carotovora. Plant Dis. 66:302306.

3. Bartz, J. A. 1988. Potential for postharvest disease in tomato fruit infiltrated with chlo- rinated water. Plant Dis. 72:9-13.

4. Bartz, J. A., and Showalter R. K. 1981. Infiltration of tomatoes by aqueous bacterial suspension. Phytopathology 71:515-518.

5. Bartz, J. A., and Eckert, J. W. 1987. Bacterial diseases of vegetable crops after harvest. Pages 351-376 in: Postharvest Physiology of Vegetables. J. Weichmann, ed. Marcel Dekker, Inc., New York.

6. Beuchat, L. R. 1999. Surface contamination of fruits and vegetables eaten raw: A review. Food Safety Unit, World Health Organization, Geneva, Switzerland.

7. Boyette, M. D., Estes, E. A., and Rubin, A. R. 1992. Hydrocooling: Maintaining the quality of North Carolina fresh produce. N.C. Agric. Ext. Serv. Circ. 414-4.

8. Ferreira, M. D., Bartz, J. A., Sargent, S. A., and Brecht, J. K. 1996. An assessment of the decay hazard associated with hydrocooling strawberries. Plant Dis. 80:1117-1122.

9. Inaba, M., Hamauzu, Y., and Chachin, K. 1996. Influence of temperature stress on color development, respiration rate, and physiological injury in harvested tomato. Bull. Univ. Osaka Pref. Ser. B. Agric. Life Sci. 48:1-11.

10. Kasmire, R. F., and Thompson, J. F. 1992. Cooling horticultural commodities. III. Selecting a cooling method. Pages 63-68 in: Postharvest Technology of Horticultural Crops. A. A. Kader, ed. Univ. Calif., Div. Agric. Nat. Res., Publ. 3311

11. Lurie, S., Handros, A., Fallik, E., and Shapira, R. 1996. Reversible inhibition of tomato fruit gene expression at high temperature: Effects on tomato fruit ripening. Plant Physiol. 110:1207-1214.

12. Mitchell, F. G. 1992. Cooling horticultural commodities. II. Cooling methods. Pages 5662 in: Postharvest Technology of Horticultural Crops. A. A. Kader, ed. Univ. Calif., Div. Agric. Nat. Res., Publ. 3311.

13. National Advisory Committee on Microbiological Criteria for Foods. 1999. Microbial safety evaluations and recommendations on fresh produce. Food Control 10:117-143.

14. Showalter, R. K. 1993. Postharvest water intake and decay of tomatoes. Hortic. Technol. 3:97-98.

15. Smith, R. E., and Bennett, A. H. 1965. Massaverage temperature of fruit and vegetables during transient cooling. Trans. ASAE. 8:249255.

16. Sommer, N. F. 1982. Postharvest handling practices and postharvest diseases of fruit. Plant Dis. 66:357-364.

17. Studer, H. E., and Kader, A. A. 1976-1977. Handling tomatoes in water. Annu. Rep. Fresh Market Tomato Res. Prog. Fresh Market Tomato Advisory Board, Bakersfield, CA.

18. Wei, C. I., Cook D. L., and Kirk J. R. 1985. Use of chlorine compounds in the food industry. Food Technol. 39:107-115.

19. White, G. C. 1992. Handbook of chlorination and alternative disinfectants. 3rd ed. Van Nostrand Reinhold, New York. 